\title{
Removing Iron Ions Contaminants from Groundwater Using Modified Nano-Hydroxyapatite by Nano Manganese Oxide
}

\author{
Mohammed Abd-El-Aal Ahmed Ayash ${ }^{1}$, Tarek Ahmed Seaf Elnasr ${ }^{2,3}$, Madiha Hassan Soliman ${ }^{4}$ \\ ${ }^{1}$ Sohag Company for Water and Waste Water, Dar El Salam, Sohag, Egypt \\ ${ }^{2}$ Chemistry Department, Faculty of Science, Al-Azhar University, Assiut, Egypt \\ ${ }^{3}$ Chemistry Department, Collage of Science, Jouf University, KSA \\ ${ }^{4}$ Chemistry Department, Faculty of Science, Helwan University, Cairo, Egypt \\ Email: *chemistayash@gmail.com, tarekseaf@gmail.com,drmadihahasan@yahoo.com
}

How to cite this paper: Abd-El-Aal Ahmed Ayash, M., Elnasr, T.A.S. and Soliman, M.H. (2019) Removing Iron Ions Contaminants from Groundwater Using Modified Nano-Hydroxyapatite by Nano Manganese Oxide. Journal of Water Resource and Protection, 11, 789-809. https://doi.org/10.4236/jwarp.2019.116048

Received: May 26, 2019

Accepted: June 27, 2019

Published: June 30, 2019

Copyright $\odot 2019$ by author(s) and Scientific Research Publishing Inc. This work is licensed under the Creative Commons Attribution International License (CC BY 4.0).

http://creativecommons.org/licenses/by/4.0/

\begin{abstract}
In this article, we study modified nano-hydroxyapatite (HAp) by nano manganese oxide $\left(\mathrm{Mn}_{3} \mathrm{O}_{4}\right)$ as adsorbent material to remove iron ions from groundwater. Different parameters were studied to option optimum conditions of removing such as contact time, $\mathrm{pH}$, initial concentration, a dosage of adsorbent, agitation speed and temperature. Kinetics studies included first order $\left(R^{2}=0.915\right)$, pseudo-first order $\left(R^{2}=0.936\right)$, second order $\left(R^{2}=0.948\right)$, pseudo-second order $\left(R^{2}=0.995\right)$, Elovich equation model $\left(R^{2}=0.977\right)$, intraparticle diffusion $\left(R^{2}=0.946\right)$, Natarajan and Khalaf $\left(R^{2}=0.915\right)$ were carried out, the obtained results revealed that the pseudo-second order is the best to describe the adsorption process because the correlation coefficient is approaching one $\left(R^{2}=0.995\right)$. Adsorption isotherm was calculated by using Freundlich, Langmuir and Temkin constants, adsorption capacity from Langmuir model was $0.606 \mathrm{mg} / \mathrm{g}$. Thermodynamic parameters $(\Delta G, \Delta H=$ $-51 \mathrm{KJ} / \mathrm{mol}$, and $\Delta S=-142(\mathrm{KJ} / \mathrm{mol}))$ for the adsorption process were also calculated and discussed.
\end{abstract}

\section{Keywords}

Groundwater, Adsorption, Nano Materials, Hydroxyapatite, Manganese Oxide, Iron Ions, Kinetic, Thermodynamic

\section{Introduction}

Groundwater is an important resource for the livelihoods and food security of 
billions of people. It is one of the most difficult problems that pollute the groundwater and the presence of iron. Therefore, in this article, we try to find a solution to the problems of iron in the groundwater [1] [2].

Among the appropriate solutions to remove or reduce the proportion of iron in the groundwater is Ion exchange [3], Reverse osmosis [4], Chemical precipitation [5], Electrolysis [6] and Adsorption [7], the choice of which depends upon the type and concentration of both sorptive material and sorbent employed, as well as their costs [8].

Among these, the adsorption method is more commonly used, adsorption is an effective technology to remove different contaminated from aqueous solutions. In this process, a very high rate of adsorption and excretion occurs. The simple function has caused this method to be one of the best ways to remove iron ions from groundwater such as Polyvinyl alcohol was used for removal of bromothymol blue and methylene blue from [9]. Removal of natural organic matter and its constituents from water by metal oxides and hydroxides based adsorbents were investigated [10]. Fluoride removal capacity from drinking water by Adsorption using nano-sized Alumina and Zirconia modified Alumina was tested [11]. Removal of $\mathrm{Cu}(\mathrm{II})$ and $\mathrm{Zn}(\mathrm{II})$ by unmodified Lignocellulosic Fibrous Layer of Palm Tree Trunk-Single was studied [12]. Removal of $\mathrm{Cu}$ (II) ions from water by rice husk (S.E. Abd Elhafez et al. 2016) [13], Pb (II), La (III), and $\mathrm{Ag}(\mathrm{I})$ ions was removed from aqueous solutions using mediated cellulose nanofibers [14]. Adsorptive of ibuprofen and diclofenac from water using metal-organic framework-derived porous carbon was investigated [15]. Removal of $\mathrm{Cr}(\mathrm{VI})$ by a free metal material containing only $\mathrm{C}, \mathrm{N}$ and $\mathrm{O}$, and having environmental friendliness, was studied [16]. Removal of benzotriazole and benzimidazole from water over a Co-based metal azolate framework MAF-5(Co) was investigated [17].

In this work, we have used modified nano hydroxyapatite by $\left(\mathrm{Mn}_{3} \mathrm{O}_{4}\right)$ nanoparticles to remove the iron ions from water by adsorption; parameters such as contact time, $\mathrm{pH}$, adsorbent dosage, stirring speed and temperature were investigated. Kinetic, Isotherm Adsorption and Thermodynamic parameters $(\Delta G$, $\Delta H$, and $\Delta S$ ) for adsorption process were also calculated and discussed.

\section{Materials and Methods}

\subsection{Apparatus}

We had all the measurements of $\mathrm{pH}$ using Misura Line $1010 \mathrm{pH}$ meter (Romania). All samples are stirred and heated by multiple Heating Magnetic Stirrer (VELP Scientifica) during experimental procedures as well, as micropipette (100 - $1000 \mu \mathrm{L}$ ) is also used. Spectrophotometer Instruments (CECIL3021), Brand (Cambridge, England). Determine the iron ions by Phenanthroline method. The samples were first mixed with $\mathrm{KBr}$ and then pressed into pellets. X-ray powder diffraction (XRD) data were collected at room temperature using a Philips 1710 Diffractometer. The patterns were run with $\mathrm{Cu}$ target and Ni filter $(\lambda=1.5418$ 
$\mathrm{A}^{\circ}$ ) at $40 \mathrm{KV}$ and $30 \mathrm{~mA}$ in the range of $2 \theta$, with a scanning speed of $06 \mathrm{deg} / \mathrm{s}$. Fourier transform infrared spectroscopy (FTIR) data were collected using a Perkin-Elmer spectrometer model 1430 in the wave number range from 4000 to 400 $\mathrm{cm}^{-1}$ Examination on the TEM: Samples were examined by carbon coated grids with a JEOL 1010 Transmission Electron Microscope, made in Japan, at the Regional Center for Mycology and Biotechnology (RCMB), Al-Azhar University.

\subsection{Procedures}

\subsubsection{Synthesis of Hydroxyapatite (HAp)}

We have prepared HAp powder using the titration between both $\mathrm{H}_{3} \mathrm{PO}_{4}$, adwic $85 \%$ in burette and $\mathrm{CaCl}_{2} \cdot 2 \mathrm{H}_{2} \mathrm{O}$, Sigma-Aldrich, $99 \%-103 \%$ in a beaker until adjustment the $\mathrm{pH}$ at a value of 10 . Through the addition of $\mathrm{NH}_{4} \mathrm{OH}$ solution (adwic 30\%) during the mixing process using a hotplate for heating the reaction mixture and stirring according to the following equation:

\section{$10 \mathrm{CaCl}_{2} \cdot 2 \mathrm{H}_{2} \mathrm{O}+6 \mathrm{H}_{3} \mathrm{PO}_{4}+20 \mathrm{NH}_{4} \mathrm{OH} \rightarrow \mathrm{Ca}_{10}\left(\mathrm{PO}_{4}\right)_{6}(\mathrm{OH})_{2}$ $+20 \mathrm{NH}_{4} \mathrm{Cl}+38 \mathrm{H}_{2} \mathrm{O}(\mathrm{I})$}

The mixture was heated in a microwave oven for $10 \mathrm{~min}$ until completely dryness and formation the precipitate, and then it was washed with distilled water and filtrated. The precipitate dried by microwave for $4 \mathrm{~min}$ [18].

\subsubsection{Synthesis of Manganese Oxide}

We can manufacture nano-manganese oxide $\left(\mathrm{Mn}_{3} \mathrm{O}_{4}\right)$ by oxidation of $\mathrm{MnCl}_{2}$ solution with a concentrated $\mathrm{H}_{2} \mathrm{O}_{2}$ solution, followed by the addition of an $\mathrm{NH}_{3}$ aq. solution. The suspension thus obtained was treated at $90^{\circ} \mathrm{C}$ [19]. With microwave for 7 mint to dryness and formation the precipitate, then it was washed with distilled water and filtrated. The precipitate dried by microwave for $3 \mathrm{~min}$.

\subsubsection{Synthesis of Modified Hydroxyapatite Manganese Hydroxide (HApMn)}

We have been able to prepare three modifications to test the removal of iron ions first (0.04 HAp:0.06 $\mathrm{Mn}_{3} \mathrm{O}_{4}$ ) second (0.06 HAp:0.04 $\mathrm{Mn}_{3} \mathrm{O}_{4}$ ) and the third (0.08 HAp:0.02 $\left.\mathrm{Mn}_{3} \mathrm{O}_{4}\right)$. The percentage of removing iron ions were $(\mathrm{R} \%)=$ $49 \%, 47 \%$, and 30\% respectively. We chose (0.06 HAp:0.04 $\mathrm{Mn}_{3} \mathrm{O}_{4}$ ) $\mathrm{R} \%=47 \%$ and have found that the best modification is. Three composed of Modification of $\mathrm{HAp}$ by $\mathrm{Mn}_{3} \mathrm{O}_{4}$ were prepared and exam to remove iron ions, to complete this study.

\subsection{Analytical Methods}

Amount of adsorbent of iron on happening at any time $\left(q_{t}\right)$ was calculated as follows [8] [9]:

$$
q_{t}=\left(C_{o}-C_{t}\right) V / m
$$

where, $C_{o}$ and $C_{t}$ are the concentrations of iron ions at initial and equilibrium time, respectively $(\mathrm{mg} / \mathrm{L}), V$ is the solution volume $(\mathrm{L})$ and $\mathrm{m}$ is the mass of dry adsorbent used (g). At equilibrium, $q_{e}=q_{t}$ and $C_{t}=C_{e}$ i therefore, the amount of 
sorbed metal ion $\left(q_{e}\right)$ was calculated according to Equation (2)

$$
q_{e}=\left(C_{o}-C_{e}\right) V / m
$$

The removal efficiency (RE\%) is calculated according to the following equation [12]:

$$
\operatorname{RE}(\%)=\left(\left(C_{o}-C_{e}\right) / C_{o}\right) \times 100
$$

\section{Results and Discussion}

\subsection{Characterizations}

Figure 1(a) shows the FTIR (Fourier transform infrared spectroscopy) of HAp. The broad bands in the regions $1600-1700 \mathrm{~cm}^{-1}$ and $3200-3600 \mathrm{~cm}^{-1}$ correspond to $\mathrm{H}-\mathrm{O}-\mathrm{H}$ bands of lattice water. The bands characteristics of the phosphate and hydrogen phosphate groups in apatite environment are observed at 565, 632, 603, 962, and $1000-1100 \mathrm{~cm}^{-1}$ for $\mathrm{PO}_{4}^{3-}$ and at $875 \mathrm{~cm}^{-1}$ for $\mathrm{HPO}_{4}^{2-}$ [18].

FTIR of the Manganese Oxide sample is shown in Figure 1(b). Several absorption bands can be observed at $500-1000 \mathrm{~cm}^{-1}$ for (Mn-O), $3000-3500 \mathrm{~cm}^{-1}$ stretching, the 1636 . While the $606,564,510.2$ and $417 \mathrm{~cm}^{-1}$ bands should be ascribed to the $\mathrm{Mn}-\mathrm{O}$ vibrations in $\mathrm{MnO}_{6}$ octahedral [19].

FTIR results indicate the presence of some bounded water to HApMn.

Figure 2(a) and Figure 2(b) shows XRD (X-ray Diffraction) patterns of the

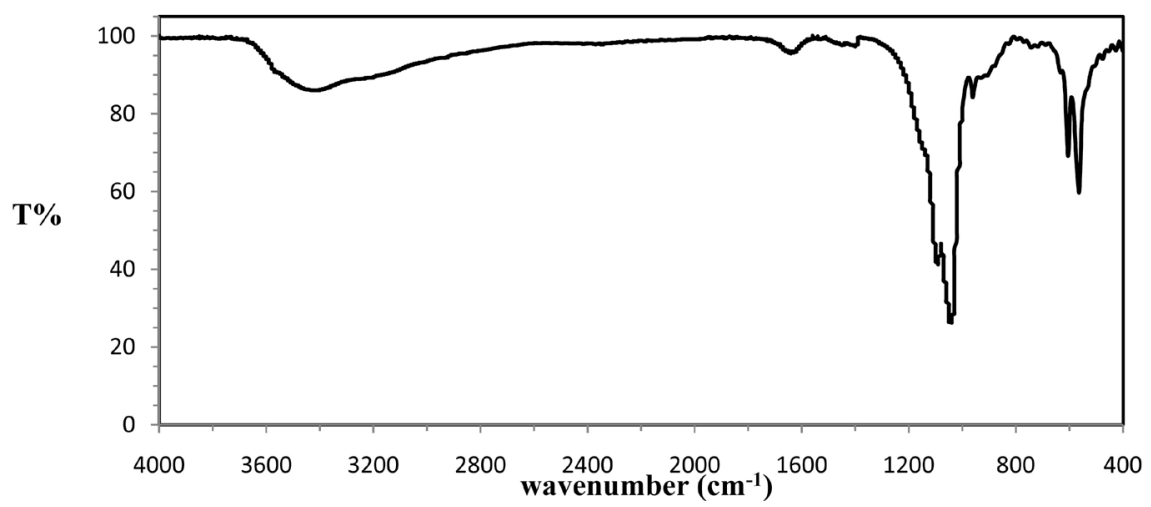

(a)

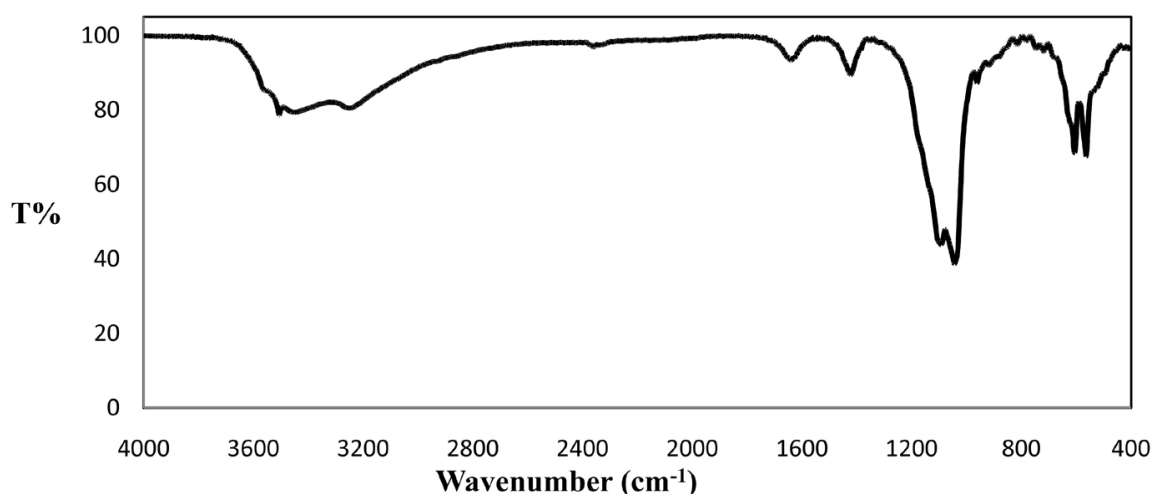

(b)

Figure 1. FTIR spectra for (a) HAp and (b) HApMn. 


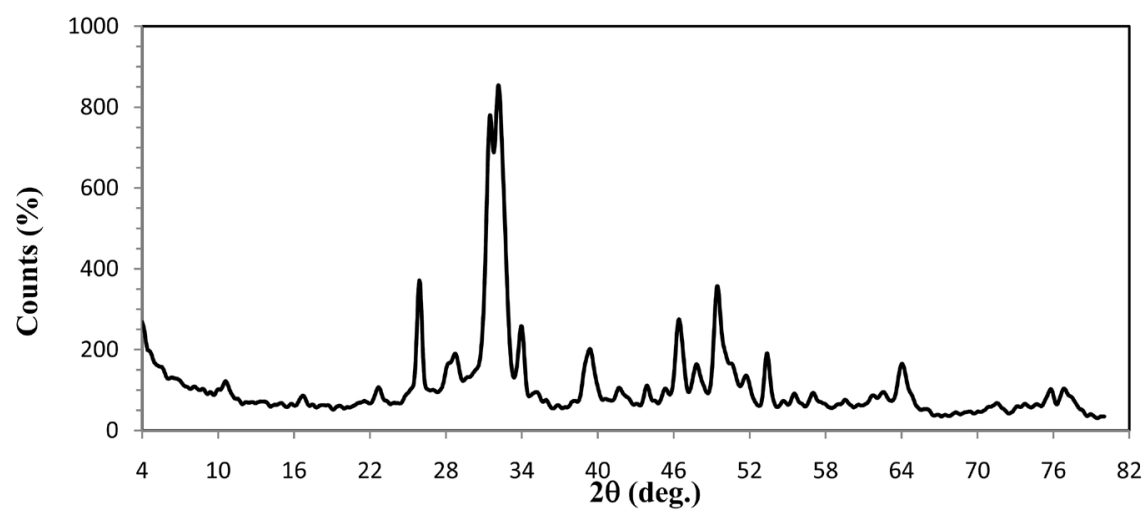

(a)

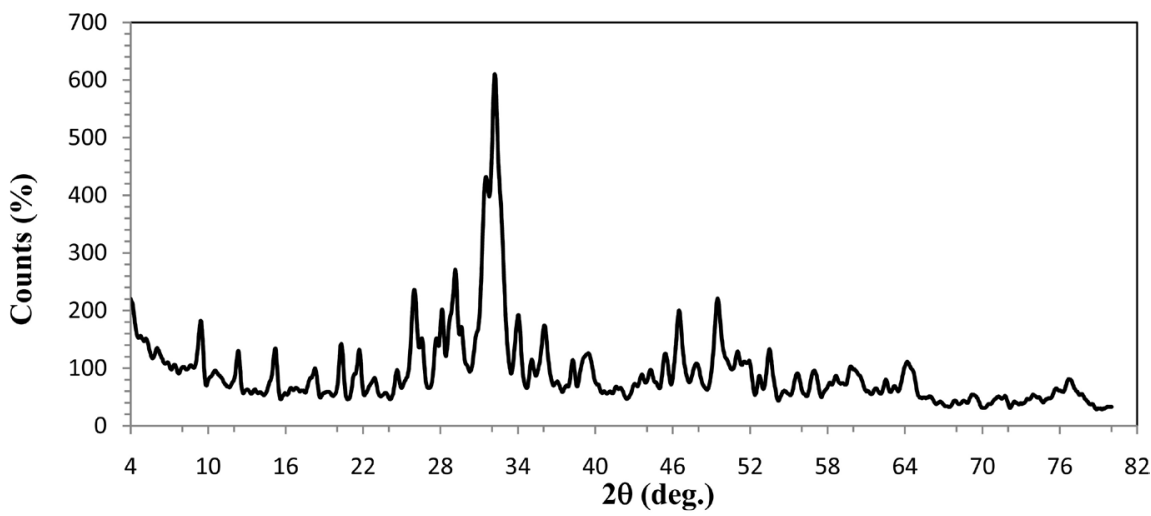

(b)

Figure 2. (a) XRD profiles for prepared HAp; (b) XRD profiles for $\mathrm{Mn}_{3} \mathrm{O}_{4}$.

HAp and $\mathrm{Mn}_{3} \mathrm{O}_{4}$ samples, respectively. The intensive diffraction peaks appeared at $25.9,28.9,31,32.3,33,33.9,36.9,39.2,44.3,46.4,47.8,49.5,51.22,53.4,58.4$, $60.2,64.5,74.4,76.7$ and 55.9 are assigned to the characteristic peaks for $\mathrm{Mn}-\mathrm{O}$, and the peaks occurred at respectively, should be ascribed to the characteristic peaks for Mn-O [19]. Hence, the sample appears to be composed of a majority of HApMn. Scherer equation can be written as [7] [20]:

$$
D=K \lambda / \beta \cos \theta
$$

where $D$ is the crystal size (nm), $\lambda$ is the wavelength of X-ray light, $\beta$ is the full width of the half maximum of the diffraction peak, and $\theta$ is the diffraction angle. Shape factor of $K$ is usually taken as 0.9 . It was found that the particle sizes were $4.2 \mathrm{~nm}$ and $3.6 \mathrm{~nm}$ for HAp and $\mathrm{Mn}_{3} \mathrm{O}_{4}$, respectively. The result is tabulated in Table 1.

Figure 3(a) and Figure 3(b) show TEM (Transmission electron microscopy) of HAp profiles and $\mathrm{Mn}_{3} \mathrm{O}_{4}$ profiles respectively.

\subsection{Study of Adsorption Factors}

We have used a Patch method for all adsorption work, $100 \mathrm{ml}$ of sample (2-10) ppm, temperature $(25-75)^{\circ} \mathrm{C}, \mathrm{pH}(3-8)$, contact time $(5-90) \mathrm{min}$, the speed of agitation $(100-8000) \mathrm{rpm}$, iron ions concentration was measured before placing 
Table 1. Size of HAp and $\mathrm{Mn}_{3} \mathrm{O}_{4}$ calculate by XRD (Scherer equation) and measured by TEM.

\begin{tabular}{ccccc}
\hline \multicolumn{2}{c}{ Calculate by Scherer equation (XRD) } & \multicolumn{3}{c}{ From TEM } \\
\hline HAp & $\mathrm{Mn}_{3} \mathrm{O}_{4}$ & & $\mathrm{HAp}$ & $\mathrm{Mn}_{3} \mathrm{O}_{4}$ \\
\hline Distance & Distance & Statistical Function & Distance & Distance \\
\hline $\mathrm{nm}$ & $\mathrm{Nm}$ & Base Unit & $\mathrm{nm}$ & $\mathrm{Nm}$ \\
\hline 22.62 & 8.91 & Count & 5 & 5 \\
26.38 & 9.09 & Mean & 23.58 & 9.20 \\
18.66 & 11.52 & Minimum & 18.66 & 8.14 \\
28.42 & 8.34 & Maximum & 28.42 & 11.52 \\
21.79 & 8.14 & Standard Deviation & 3.86 & 1.35 \\
& & Cal. by XRD & 4.2 & 3.6 \\
\hline
\end{tabular}
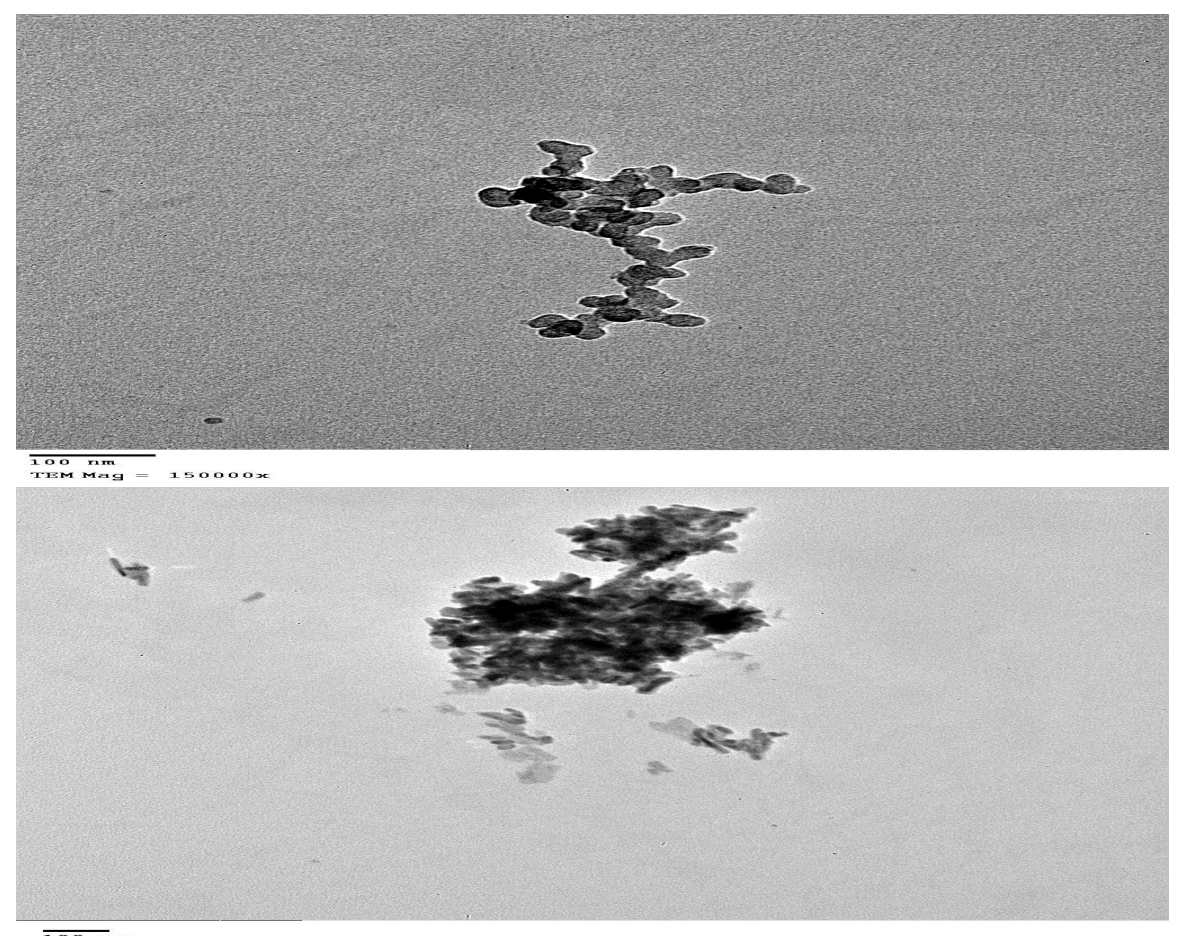

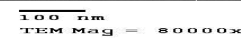

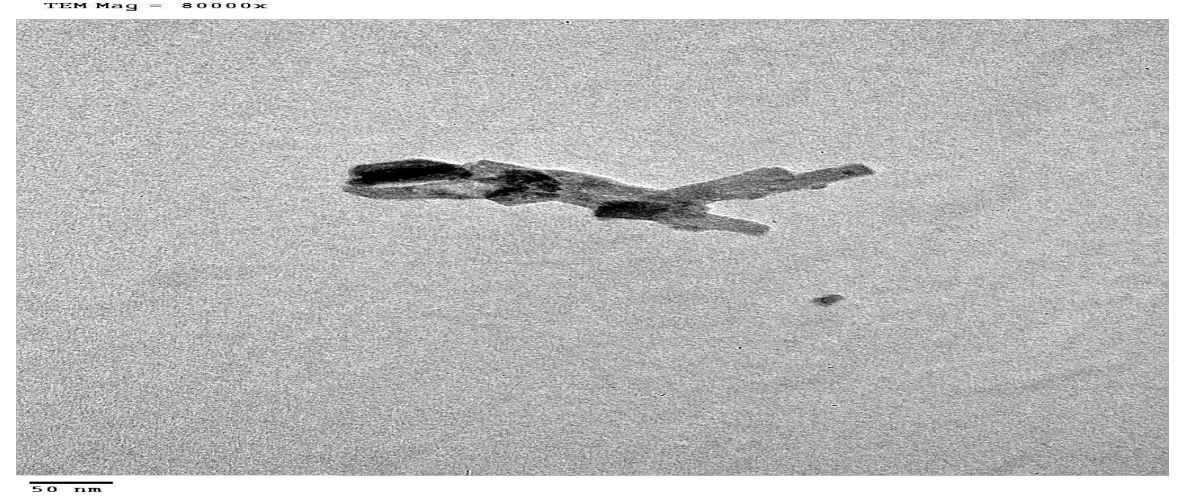

(a) 

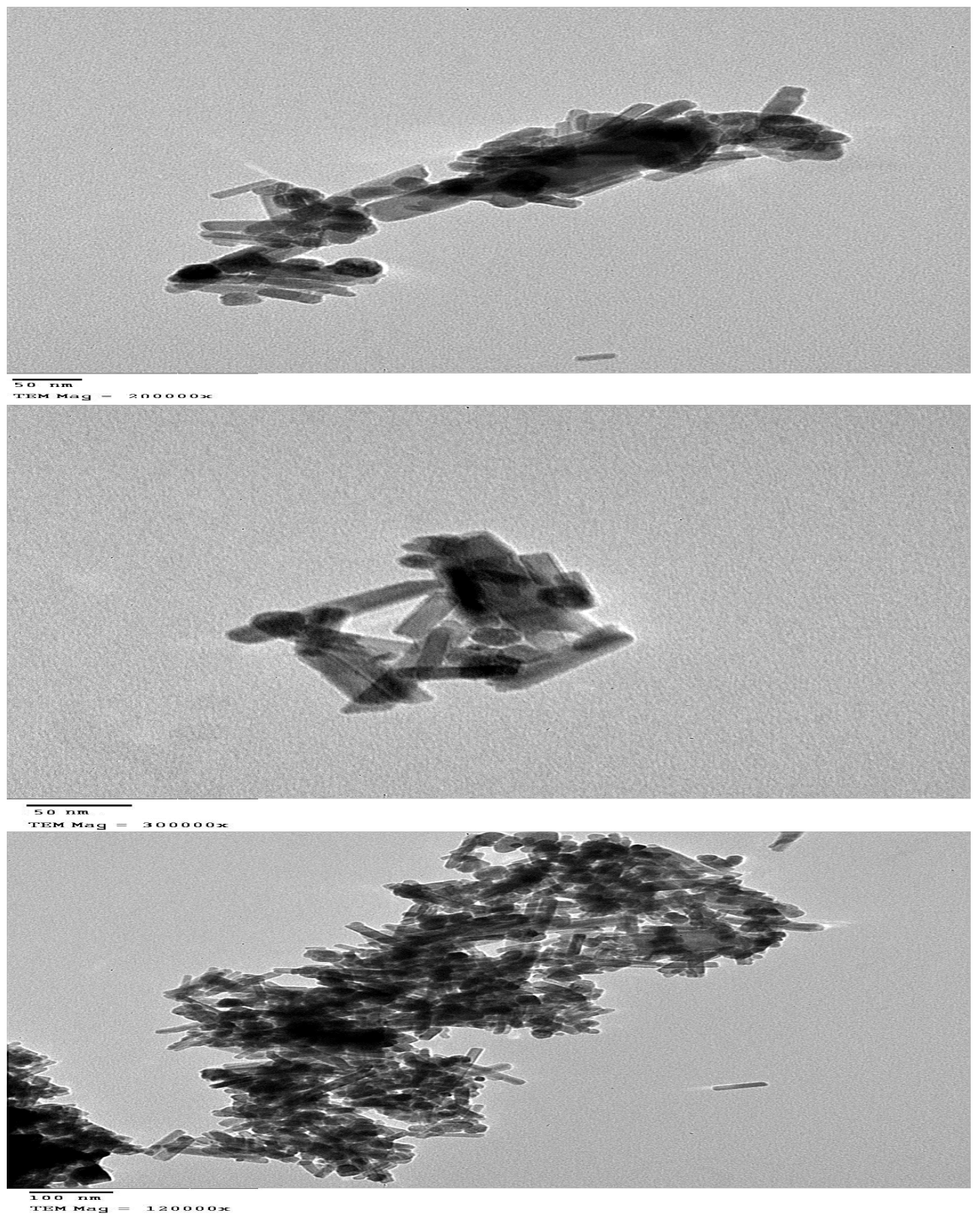

(b)

Figure 3. (a) TEM profiles for prepared of HAp; (b) TEM profiles for prepared $\mathrm{Mn}_{3} \mathrm{O}_{4}$.

the adsorbent and after putting them for different samples obtained from different wells as shown in Table 2. Various adsorption parameters for the effective removal of iron ions using modified hydroxyapatite as an adsorbent from aqueous solution were studied and optimized.

\subsubsection{Effect of Contact Time}

We have studied the effect of contact time in different time periods ranging from 5 to $90 \mathrm{~min}$ with the initial metal concentration of $2 \mathrm{ppm}$ iron ions in presence $0.1 \mathrm{~g}$ of HApMn with continuous stirring at $400 \mathrm{rpm}$ and at pH 6 [21]. Remove iron ions over time, where it was about $25 \%$ in 5 minutes and reached $60 \%$ in 90 minutes see Figure 4.

\subsubsection{Effect of $\mathrm{pH}$}

$\mathrm{PH}$ is an important factor in the adsorption process. The $\mathrm{pH}$ of $3-8$ is determined 
Table 2. Iron ion concentrations of well samples before and after treatment.

\begin{tabular}{ccccc}
\hline no & Place (well name) & well name & Before Ppm & After Ppm \\
\hline $\mathbf{1}$ & New Awolad Khalf & 3 & 0.94 & 0.22 \\
$\mathbf{2}$ & New Awolad Khalf & 4 & 1.03 & 0.23 \\
$\mathbf{3}$ & New Awolad Khalf & 5 & 1.1 & 0.24 \\
$\mathbf{4}$ & Arab Elataiat south & 2 & 0.68 & 0.155 \\
$\mathbf{5}$ & Old Elkhamima & 3 & 0.58 & 0.12 \\
\hline
\end{tabular}

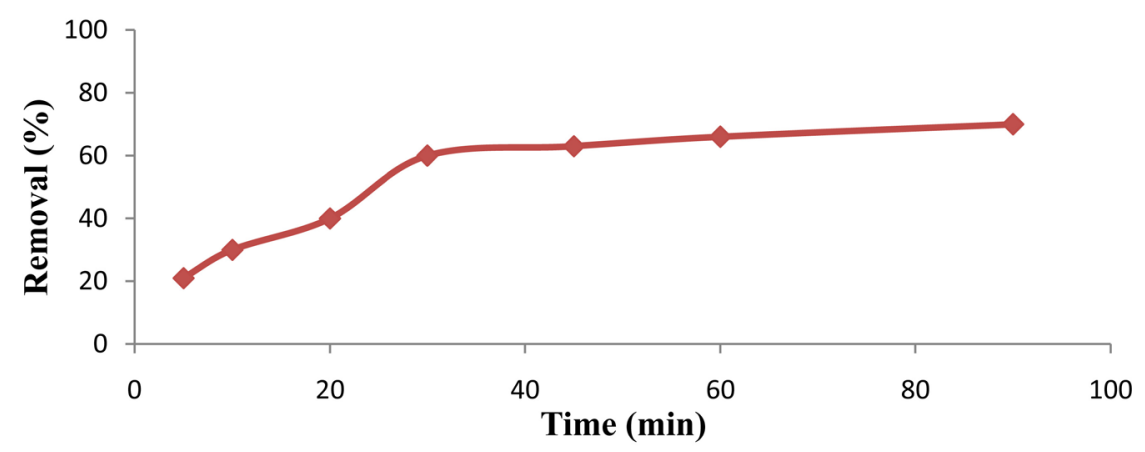

Figure 4. Effect of contact time on iron ions removal using HApMn.

by using $30 \%$ ammonia solution or $37 \%$ hydrochloric acid solution and the same conditions as above. Note that the increase in $\mathrm{pH}$ increases the removal iron ions (see Figure 5). It may be due to precipitation of iron ions as $\mathrm{Fe}^{+3}$ hydroxide brown precipitate [22].

\subsubsection{Effect of Agitation Speed}

The effect of the stirring speed on the removal of iron ions under the same experimental conditions is studied by agitation Speed $(100-800) \mathrm{rpm}$. The efficiency of the removal was found to increase with increased agitation speed (see Figure 6). Iron ions increase the speed of stirring [23].

\subsubsection{Effect of Initial Concentration of Iron Ions}

By studying the effect of iron ion concentration per $100 \mathrm{ml}$, we found that the removal efficiency was reduced by increasing the concentration of iron per 100 $\mathrm{ml}$ see Figure 7 [24].

\subsubsection{Effect of Temperature}

Under the same experimental conditions the effect of temperature on iron ions removal was studied by varying the temperature from $25^{\circ} \mathrm{C}$ to $75^{\circ} \mathrm{C}$. As we see from Figure 8, as the temperature increases the removal percentage increase [25].

\subsubsection{Applications of the Method}

Around $100 \mathrm{ml}$ of sample (well water) at $\mathrm{pH}$ about 7.4, the temperature at $30^{\circ} \mathrm{C}$, stirring at $400 \mathrm{rpm}$, stirring time $30 \mathrm{~min}$ was used to measure iron ions concentrations. 


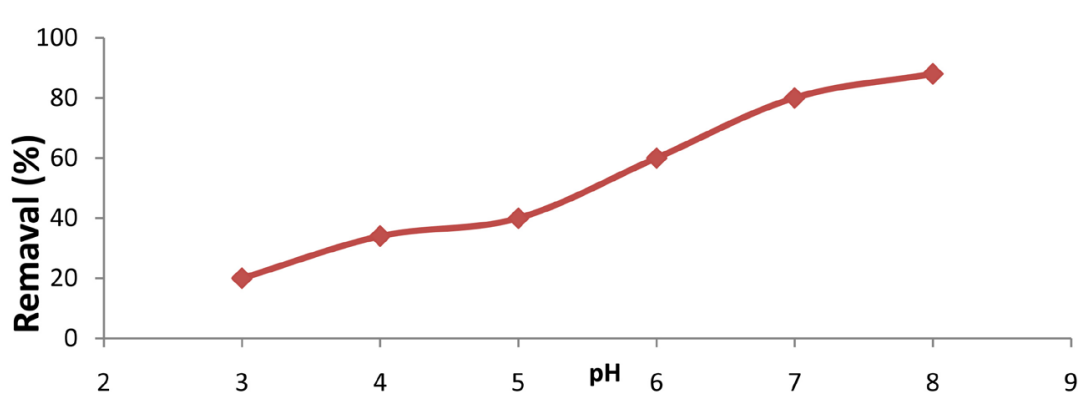

Figure 5. Effect of $\mathrm{pH}$ on iron ions removal using HApMn.

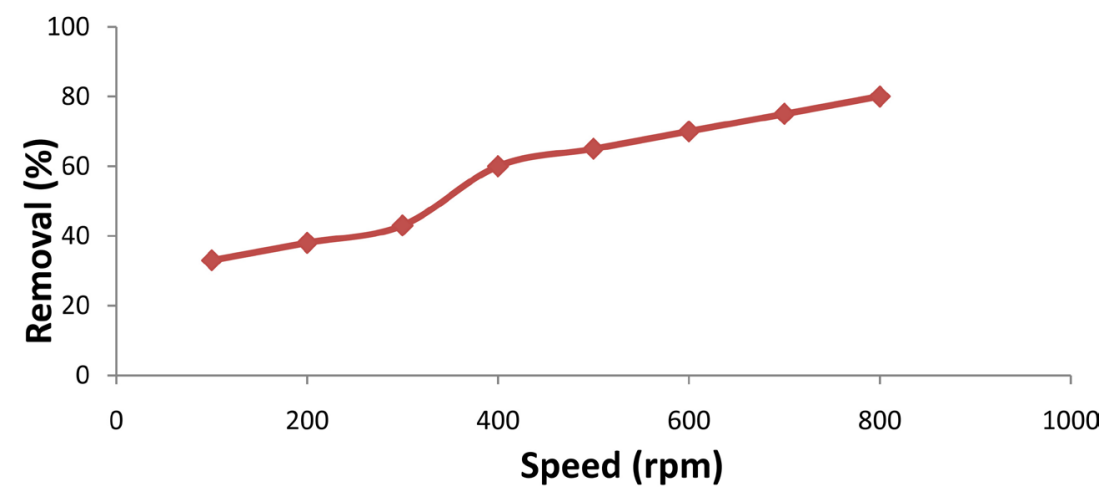

Figure 6. Effect of agitation speed on iron ions removal using HApMn.

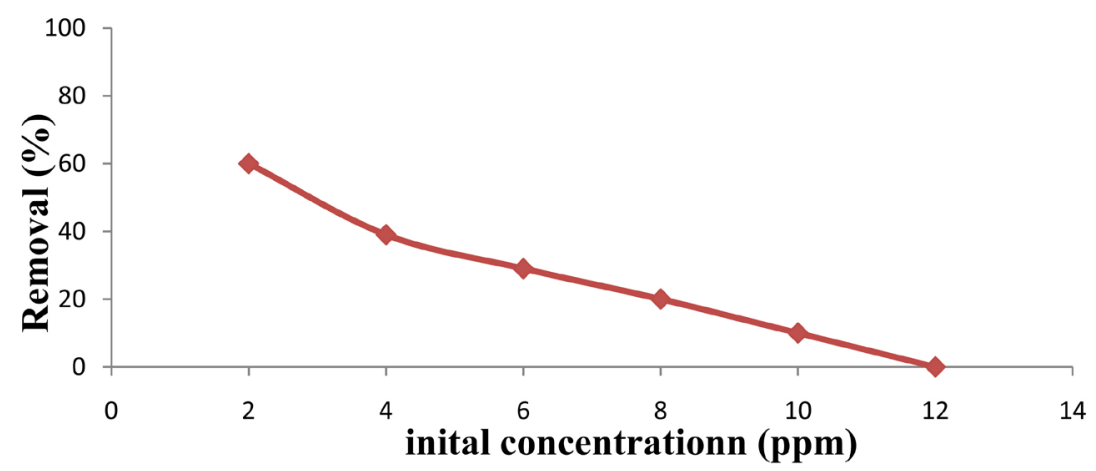

Figure 7. Effect of initial concentration on iron ions removal using HApMn.

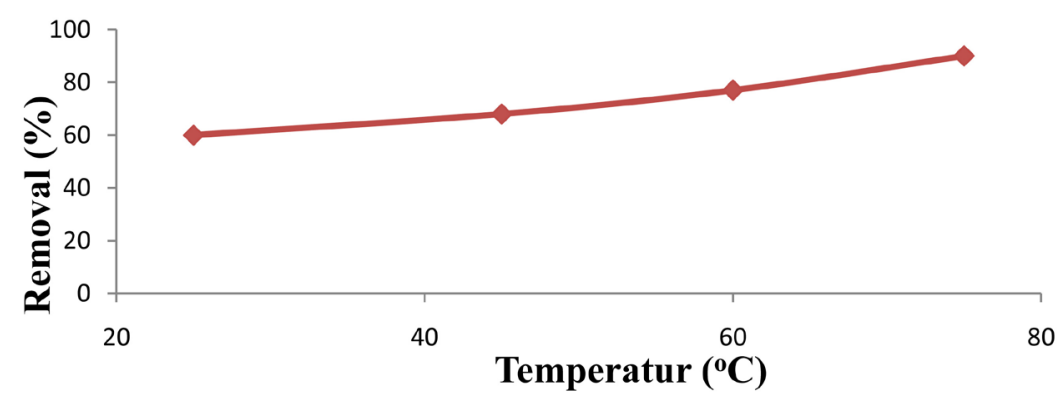

Figure 8. Effect of temperature on iron ions removal using HApMn.

\subsection{Kinetics Modeling}

We have done a study the kinetic of adsorption and adsorption rate controls; we 
found a metal ion uptake rate with a residence time of adsorbate uptake at solid interface solution. We have studied seven equations models, the first-order rate equation, pseudo-first order rate equation, second-order rate equation, pseudo-second order rate equation, intra-particle diffusion, and Elovich equations. See Table 3 for the parameter values.

\subsubsection{First Order Kinetic Equation}

The equation of a straight line is applicable [12] [26]:

$$
-\ln \left(C_{t} / C_{o}\right)=K_{1} t
$$

where, $C_{t}(\mathrm{mg} / \mathrm{L})$ is the concentration at a given time $t$ and $C_{o}(\mathrm{mg} / \mathrm{L})$ is initial concentration of iron ions in solution. $K_{1}\left(\mathrm{~min}^{-1}\right)$ is the first order rate constant. The regression $R^{2}$ obtained by the linear plot of $-\ln \left(C_{t} / C_{o}\right)$ against $t$ (Figure 9), is shown in Table $3, R^{2}$ was greater than 0.9 , which indicates a good fit to the experimental data.

\subsubsection{Second Order Kinetic Equation}

The linear version is given by this relationship [12] [26]:

$$
\left(1 / C_{t}\right)-\left(1 / C_{o}\right)=K_{2} t \text {. }
$$

where, $k_{2}[\mathrm{~L} / \mathrm{mg} / \mathrm{min}]$ is the second order rate constant for the adsorption process, determined from the linear plot of $\left(1 / C_{t}-1 / C_{o}\right)$ against $t$, shown in (Figure 10) for iron ions. See Table 3, for the value of the constants. The

\begin{tabular}{|c|c|c|c|}
\hline No & Kinetics model & Parameters & Value \\
\hline \multirow{2}{*}{1} & First-order rate equation & $K_{1}\left(\min ^{-1}\right)$ & 0.0116 \\
\hline & $-\ln \left(C_{t} / C_{o}\right)=K_{1} t$ & $R^{2}$ & 0.915 \\
\hline \multirow{2}{*}{2} & Second order rate equation & $K_{2}(\mathrm{~L} / \mathrm{mg} \cdot \min )$ & 0.013 \\
\hline & {$\left[1 / C_{t}\right]-\left[1 / C_{o}\right]=K_{2} t$} & $R^{2}$ & 0.948 \\
\hline \multirow{2}{*}{3} & Lagergren pseudo first-order equation. & $K_{1}\left(\min ^{-1}\right)$ & -0.018 \\
\hline & $\operatorname{Ln}\left(q_{e}-q_{t}\right)=\ln q_{e}-K_{1} t$ & $R^{2}$ & 0.936 \\
\hline \multirow{3}{*}{4} & & $K_{2}(\mathrm{~g} / \mathrm{mg} \cdot \mathrm{min})$ & 0.036 \\
\hline & $\begin{array}{l}\text { Pseudo second-order rate equation } \\
\qquad t / q_{t}=1 / K_{2} q_{e}^{2}+t / q_{e}\end{array}$ & $q_{e}$ & 1.677 \\
\hline & & $R^{2}$ & 0.995 \\
\hline \multirow{3}{*}{5} & \multirow{3}{*}{$\begin{array}{l}\text { Intraparticle diffusion } \\
\qquad q_{t}=K_{p} t^{1 / 2}+c\end{array}$} & $c(\mathrm{mg} / \mathrm{g})$ & 0.196 \\
\hline & & $R^{2}$ & 0.946 \\
\hline & & $K_{\mathrm{p}}\left(\mathrm{mg} / \mathrm{g} \cdot \mathrm{min}^{1 / 2}\right)$ & 0.143 \\
\hline \multirow{3}{*}{6} & & $R^{2}$ & 0.977 \\
\hline & $\begin{array}{c}\text { Elovich equation model } \\
q_{t}=[1 / \beta] \ln [\alpha \beta]+[1 / \beta] \ln t\end{array}$ & $\alpha$ & 0.214 \\
\hline & & $\beta(\mathrm{g} / \mathrm{mg})$ & 2.691 \\
\hline \multirow{2}{*}{7} & Natarajan and Khalaf & $K\left(\min ^{-1}\right)$ & 0.0116 \\
\hline & $\operatorname{Ln}\left(C_{o} / C_{t}\right)=K t$ & $R^{2}$ & 0.915 \\
\hline
\end{tabular}

Table 3. Summary of kinetic modeling parameters. 


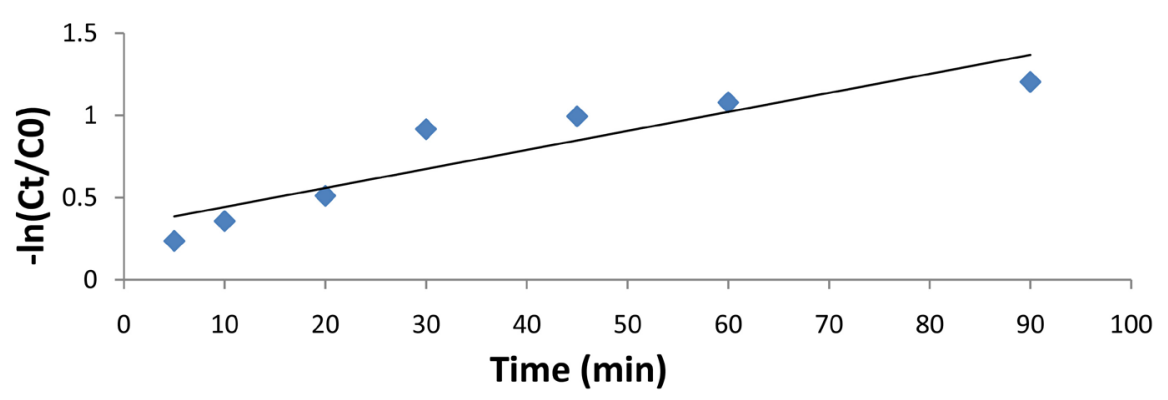

Figure 9. First Order Kinetic Equation plot for the adsorption of iron ions on HApMn.

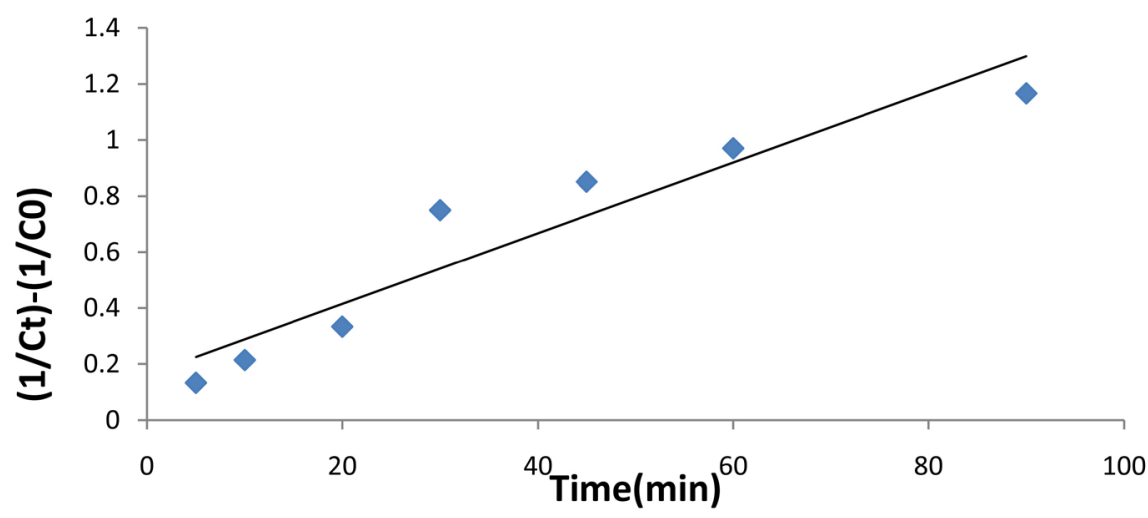

Figure 10. Second order rate equation plot for the adsorption of iron ions on HApMn.

regression value $\left(R^{2}\right)$ is greater than 0.9 for iron ions. Indicating that the equation can be applied to experimental data for iron ions.

\subsubsection{Pseudo First Order Kinetic Equation}

The mathematical relationship to describe the pseudo-motif model proposed by Lagergren is shown in equation [12] [27]:

$$
\ln \left(q_{e}-q_{t}\right)=\ln q_{e}-K_{1} p_{t}
$$

where $K_{1}$ is the rate constant of pseudo-first order adsorption (L/min). $q_{e}$ and $q_{t}$ are adsorption capacity $(\mathrm{mg} / \mathrm{g})$ at equilibrium and at any time $t$, respectively. The value of the constants $q_{\mathrm{e}} k_{1}$ and $R^{2}$ obtained from the linear plot of $\ln \left(q_{e}-\right.$ $q_{t}$ ) vs $t$ (Figure 11) are shown in Table 3. The regression rate $R^{2}>0.9$ For iron ions.

\subsubsection{Pseudo-Second Order Kinetic Equation}

The linear relationship of pseudo-second order kinetic model is given by [12] [23] [24] [25] [27] [28]:

$$
t / q_{t}=1 / K_{2} q_{e}^{2}+t / q_{e}
$$

where $K_{2}(\mathrm{~g} / \mathrm{mg} / \mathrm{min})$ is the rate constant of pseudo-second order adsorption rate constant. The values of $k_{2}, R^{2}$ and $q_{e}$ were calculated from the plots of $t / q_{t}$ on the vertical axis, and $t(\mathrm{~min})$ on the horizontal axis (Figure 12) as shown in Table 3. The regression $R^{2}>0.9$, for iron meaning that this model provided the best fit for the adsorption data. 


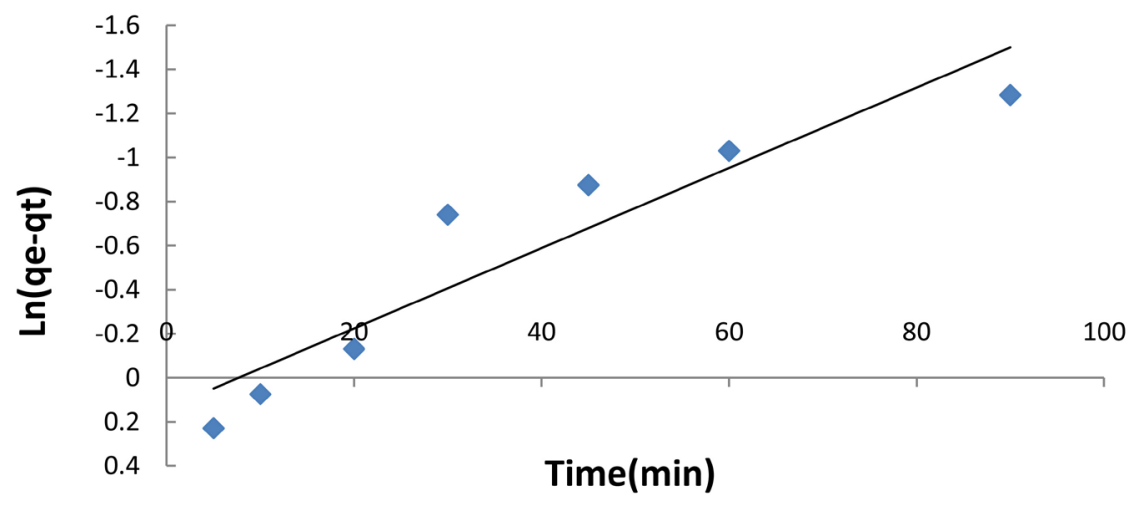

Figure 11. Pseudo first-order kinetic plot for the adsorption of iron ions on HApMn.

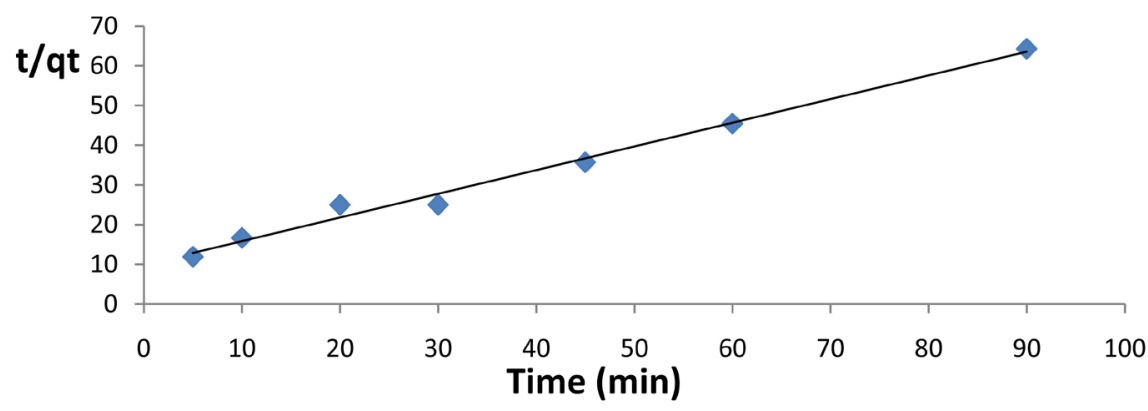

Figure 12. Pseudo second order rate plot for the adsorption of iron ions on HApMn.

\subsubsection{Elovich Equation}

The Elovich equation used to describe the kinetics of chemisorption of gas on solids, The linear relationship is given by [12] [23] [24] [25] [27] [28]:

$$
q_{t}=(1 / \beta) \ln (\alpha \beta)+(1 / \beta) \ln t
$$

where, the constants $\alpha$ and $\beta$ were obtained from the slope and intercept of the linear plot of $q_{t}(\mathrm{mg} / \mathrm{g})$ against $\ln (t, \mathrm{~min})$ as shown in (Figure 13$)$, for the adsorption of iron ions on HApMn.

\subsubsection{Intra-Particle Diffusion Rate Equation}

The intra-particle diffusion equation [12] [28] [29] [30] is given as Equation (10) shown in Figure 14.

$$
q_{t}=k p_{t}^{1 / 2}+C
$$

where, $K_{p}\left(\mathrm{mg} / \mathrm{g} \cdot \mathrm{min}^{1 / 2}\right)$ is the intraparticle diffusion rate constant and $C$ is the intercept. by drawing $q_{t}$ on the $\mathrm{Y}$-axis against $t(\mathrm{~min})$ on $\mathrm{X}$-axis we can find the slope, intercept and correlation coefficient as seen in Table 3, it was observed that the intraparticle diffusion rate constant increased with an increase in initial concentrations.

\subsubsection{Natarajan and Khalaf}

Natarajan and Khalaf equation [31] developed a relationship between the initial concentration and concentration at any time. The linear form is expressed as:

$$
\ln \left(C_{o} / C_{t}\right)=K_{n} \cdot t
$$




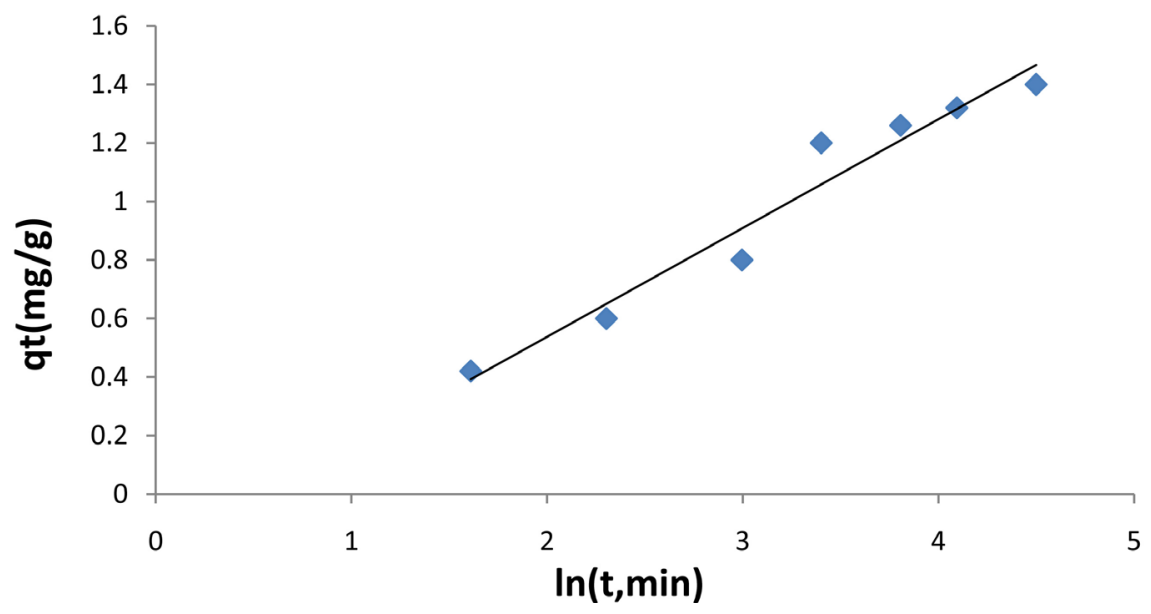

Figure 13. Elovich plot for the adsorption of iron ions on HApMn.

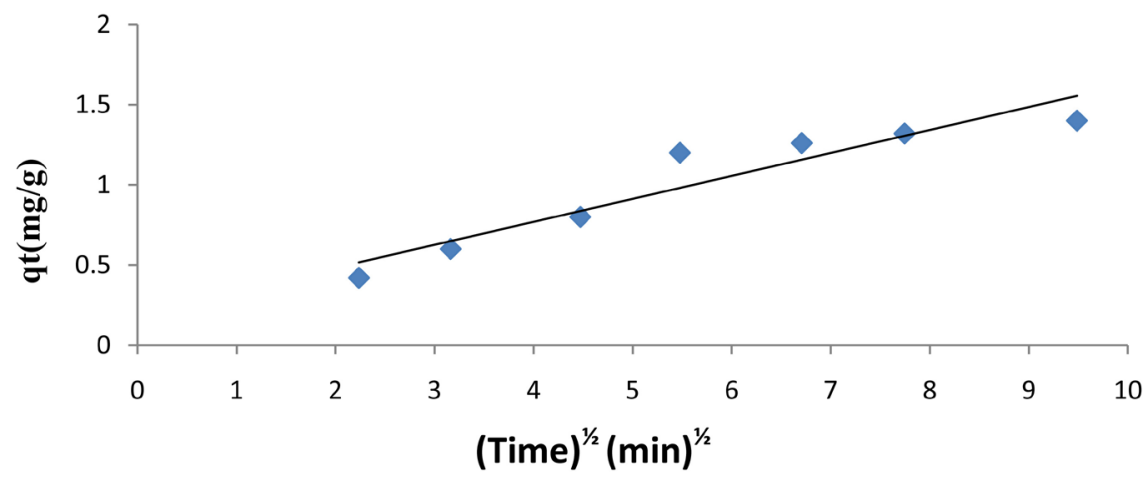

Figure 14. Intraparticle diffusion equation plot for the adsorption of iron ions on HApMn.

where, $C_{t}$ is the concentration of iron $(\mathrm{mg} / \mathrm{L})$ at time $t$. The plot of $\ln \left(C_{o} / C_{t}\right)$ against $t$ will give a straight line and the value of $k_{n}$ can be obtained from the slope of the graph (Figure 15). The values of $k_{n}$ and $R^{2}$ are shown in Table 3. The correlation coefficient $\mathrm{R} 2$ for the pseudo second order kinetic model is greater than 0.99 .

\subsection{Adsorption Isotherms}

Adsorption data are generally described by adsorption isotherms, such as Freundlich, Langmuir, and Temkin isotherm models.

\subsubsection{Freundlich Isotherm}

This model proposes monolayer sorption with a heterogeneous energy distribution of active sites, accompanied by interactions between adsorbed molecules. The general form of this model is presented in the following equation [12] [32]:

$$
q_{e}=K_{F} C_{e} 1 / n
$$

The linear form of the Equation (12) is [12] [33]:

$$
\ln q_{e}=\ln K_{F}+1 / n \ln C_{e}
$$

This isotherm relates the amount of solute adsorbed at equilibrium per weight 


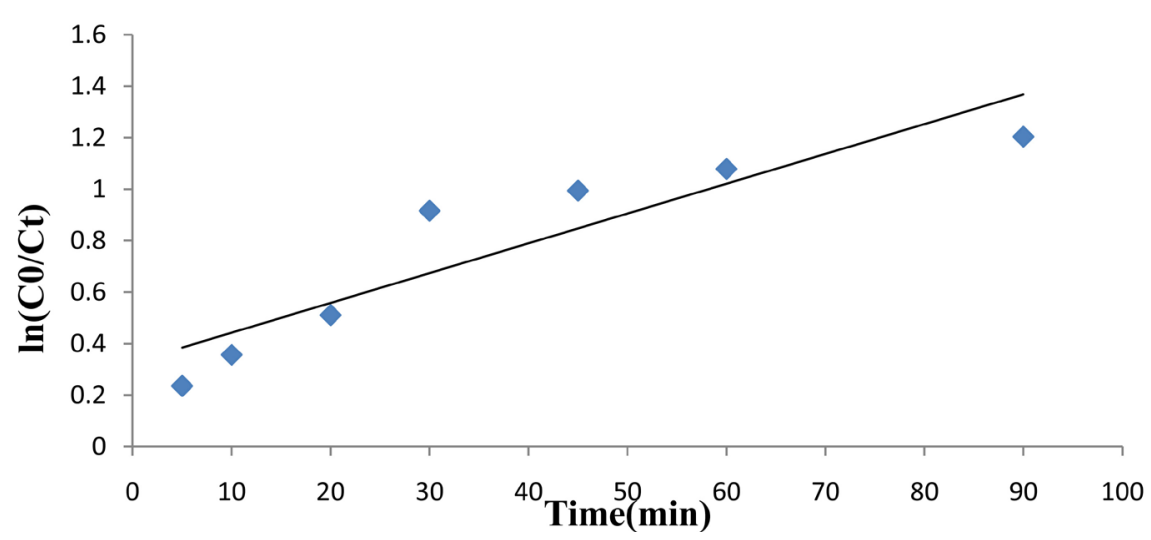

Figure 15. Natarajan and Khalaf plot for the adsorption of iron ions on HApMn.

of adsorbent where $q_{e}(\mathrm{~mol} / \mathrm{g})$ to the adsorbate concentration at equilibrium $C_{e}$ $\left(\mathrm{mol} / \mathrm{dm}^{3}\right)$, is the most widely non-linear sorption models used. $K_{F}(\mathrm{mg} / \mathrm{g})$ stands for adsorption capacity and $1 / n$ stands for adsorption intensity.

By plotting of $\ln q_{e}$ on $\mathrm{Y}$-axis versus $\ln C$ on X-axis we can determine $K_{F}$ and $1 / n$ from a slope and intercept respectively (Figure 16).

\subsubsection{Langmuir Isotherm}

The Langmuir model [8] [26] [29] [32] describes adsorption as a monolayer surface corresponding to solids with identical homogeneous sites. This is according to the following linear relationship:

$$
C_{e} / q_{e}=1 /\left(q_{\max } b\right)+\left(1 / q_{\max }\right) C
$$

where $q_{e}$ is the amount adsorbed $(\mathrm{mg} / \mathrm{g}), C_{e}$ is the equilibrium concentration of the adsorbate ions $(\mathrm{mg} / \mathrm{L}), q_{\max }$ and $b$ are Langmuir constants. Where, $\mathrm{q}_{\max }$ $(\mathrm{mg} / \mathrm{g})$ is Langmuir constant related to maximum adsorption capacity (monolayer capacity) andb $(\mathrm{L} / \mathrm{mg})$ is the energy of adsorption.

By plotting of $C_{e} / q_{e}$ versus $C_{e}$ should indicate a straight line of slope $1 / q_{\max }$ and an intercept of $1 / q_{\max } b$.

Figure 17: shows Langmuir isotherm for iron ions adsorption at various initial iron ions concentrations using HApMn at adsorbent dosage of $0.1 \mathrm{~g}$, agitation speed of $400 \mathrm{rpm}$, solution $\mathrm{pH} 6$ and temperature of $30^{\circ} \mathrm{C}$. Based on the correlation coefficient $\left(R^{2}\right)$ shown in Table 4 the adsorption isotherm can be better described by Langmuir equation. Also, the Langmuir equation yields a better fit of the experimental data than the Freundlich equation. Further, the essential characteristics of Langmuir isotherm can be described by a separation factor $R_{L}$, which indicates the shape of the isotherm and nature of the adsorption process. this is expressed by the following equation [8] [29] [30] [34].

$$
R_{L}=\left[1 /\left(1+b C_{o}\right)\right]
$$

where $C_{o}$ is the initial concentration of iron ions $(\mathrm{mg} / \mathrm{L})$. The separation factor When $R_{L}$ is greater than 1, the process is unfavourable, $R_{L}=1$, Linear, $0<R_{L}<1$, favorable and $R_{L}=0$ irreversible. In this study, the Calculated values for $R_{L}$ are 
Table 4. Adsorption isotherms constants.

\begin{tabular}{cccccccccc}
\hline \multicolumn{3}{c}{ Freundlich } & \multicolumn{4}{c}{ Langmuir } & \multicolumn{3}{c}{ Temkin } \\
\hline$K_{f}(\mathrm{mg} / \mathrm{g})$ & $1 / \boldsymbol{n}$ & $\boldsymbol{R}^{2}$ & \multicolumn{2}{c}{$\boldsymbol{q}_{\max }(\mathrm{mg} / \mathrm{g}) \boldsymbol{B}(\mathrm{L} / \mathrm{mg})$} & $\boldsymbol{R}^{2}$ & $\boldsymbol{K} T(\mathrm{~L} / \mathrm{mg})$ & $\boldsymbol{\beta}(\mathrm{g} / \mathrm{mg})$ & $\boldsymbol{R}^{2}$ \\
\hline 1.255 & -0.222 & 0.799 & 0.603 & -0.837 & 0.958 & 0.002 & -0.201 & -0.853 \\
\hline
\end{tabular}

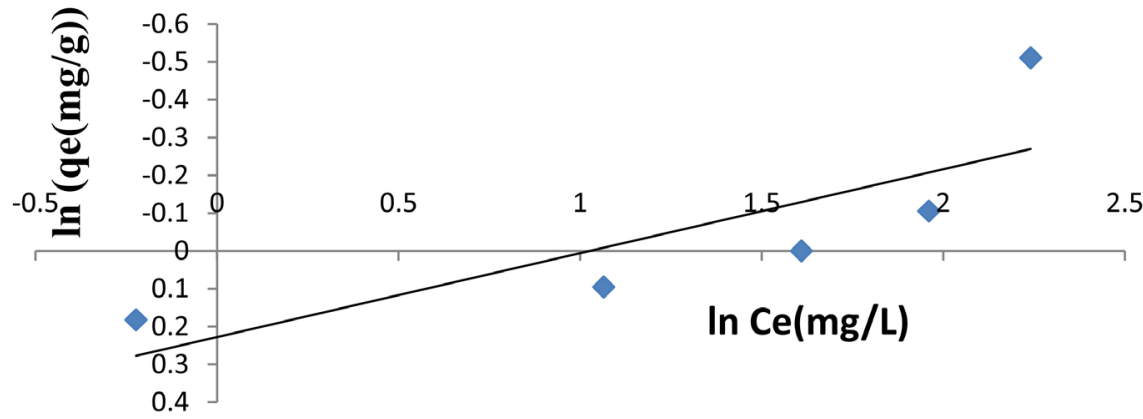

Figure 16. Freundlich isotherm for iron ions sorption on HApMn.

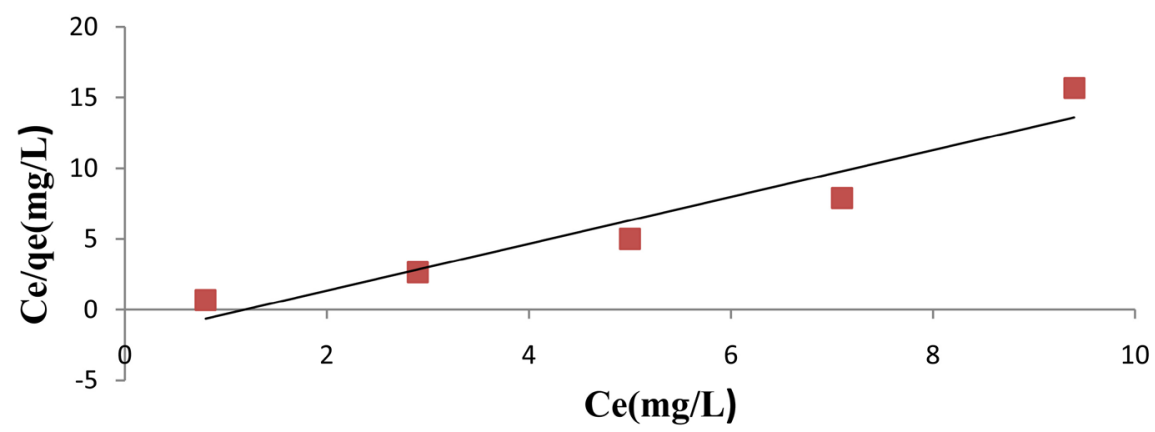

Figure 17. Langmuir isotherm for iron ions adsorption on HApMn.

found to be a fraction in the range of $0-1(0.442)$, an indication that the adsorption process is favorable [35].

\subsubsection{Temkin Isotherm}

The linear form of the Temkin equation is given by [8] [29] [30] [36]:

$$
q_{e}=\beta \ln K T+\beta \ln C_{e}
$$

where, $\beta$ which is related to the heat of adsorption, and $K T(\mathrm{~L} / \mathrm{mg})$ is the equilibrium binding constant corresponding to the maximum binding energy. By plotting $q_{e}$ on $\mathrm{Y}$-axis versus on X-axis we can be calculated $\beta$ and KT calculated from the slope and the intercept. Figure 18: shows Temkin model isotherm for iron ions adsorption at various initial iron ions concentrations using HApMn at adsorbent dosage of $0.1 \mathrm{~g}$, agitation speed of $400 \mathrm{rpm}$, solution $\mathrm{pH} 6$ and temperature of $25^{\circ} \mathrm{C}$.

\subsection{Thermodynamic Parameters}

Thermodynamic parameters [37] such as and entropy $(\Delta S)$, enthalpy $(\Delta H)$ and free energy $(\Delta G)$ were determined using Equations (16)-(19): 


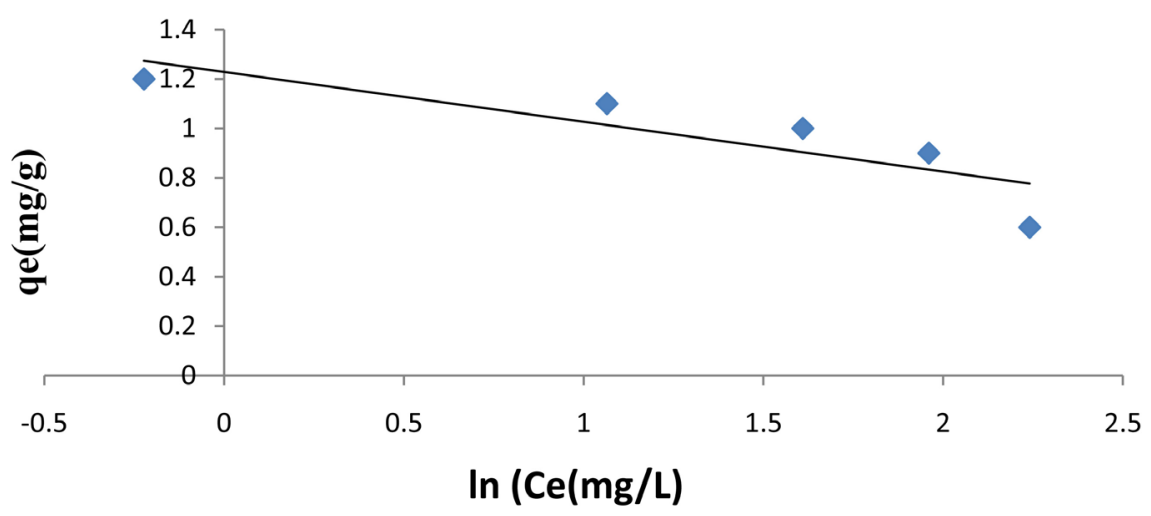

Figure 18. Temkin model plot for Adsorption of iron on HApMn.

$$
\begin{gathered}
K_{c}=q_{e} / C_{e} \\
\Delta G=-R T \ln K_{c} \\
\operatorname{Ln}_{c}=(-\Delta H / R)(1 / T)+\Delta S / R
\end{gathered}
$$

where $q_{e}$ is the amount of solute adsorbed on the adsorbent cubic decimeter of the solution at equilibrium, $K_{c}$ is the equilibrium constant, and $C_{e}\left(\mathrm{~mol} / \mathrm{dm}^{3}\right)$ is the equilibrium concentration of the solute in solution, $T$ is temperature in Kelvin and $R(8.314 \mathrm{~J} / \mathrm{K} / \mathrm{mol})$ is the gas constant. By plotting of on $\mathrm{Y}$-axis against $1 / T$ on $\mathrm{X}$-axis we found $\Delta H$ and $\Delta S$ were obtained from the slope and intercept of Vant Hoff isotherm (Figure 19). Table 5 shows the calculated values of the thermodynamic parameters.

In order to understand this process better, we must calculate the entropies and enthalpies of temperature periods using the previous equations [32] [38]:

$$
\Delta G^{\circ}=\Delta H^{\circ}-T \Delta S^{\circ}
$$

where, $K_{c 1}$ is the equilibrium constant at temperature $T_{1}$ and $K_{c 2}$ are the equilibrium constant at temperature $T_{2}$.

Increasing the value of $\Delta G^{\circ}$ with increasing temperature leads to the process of adsorption of iron ions on HApMn become preferred in low temperatures. The negative value of $\Delta H^{\circ}$ proves that the adsorption process was exothermic reaction and a certain amount of heat developed during the iron ions that adsorbed on the surface of the adsorbents. The more negative value of $\Delta S^{\circ}$, the more degree of randomization in the solid/liquid interface during the absorption process where entropy expresses the amount of randomness or disorder in the system. We used entropy $\left(\Delta S^{\circ}\right)$ to determine the degree of disorder or randomness in the system. We know that the higher the negative values of $\Delta S^{\circ}$, the lower the degree of randomization in the solid/liquid interface during the adsorption process [39]. The values of $\Delta H^{\circ}$ and $\Delta S^{\circ}$ calculated from the plot of $\ln K$ versus $1 / T$.

The value of $\Delta H^{\circ}$ was negative, indicating that the adsorption reaction was exothermic (high heat of adsorption). Another equation that has been used to determine the possible adsorption mechanism is the Dubinin-Radushkevick 
Table 5. Thermodynamic parameters for adsorption of iron ions on HApMn.

\begin{tabular}{cccccc}
\hline$T(K)$ & $K_{c}$ & $\Delta G(\mathrm{~kg} / \mathrm{mol})$ & $\Delta H$ & $\Delta S$ & $R^{2}$ \\
\hline 298 & 1.5 & 0.405 & & & \\
318 & 0.379 & -0.969 & -51 & -142 & 0.991 \\
333 & 0.200 & -1.609 & & & \\
348 & 0.127 & -2.605 & & & \\
\hline
\end{tabular}

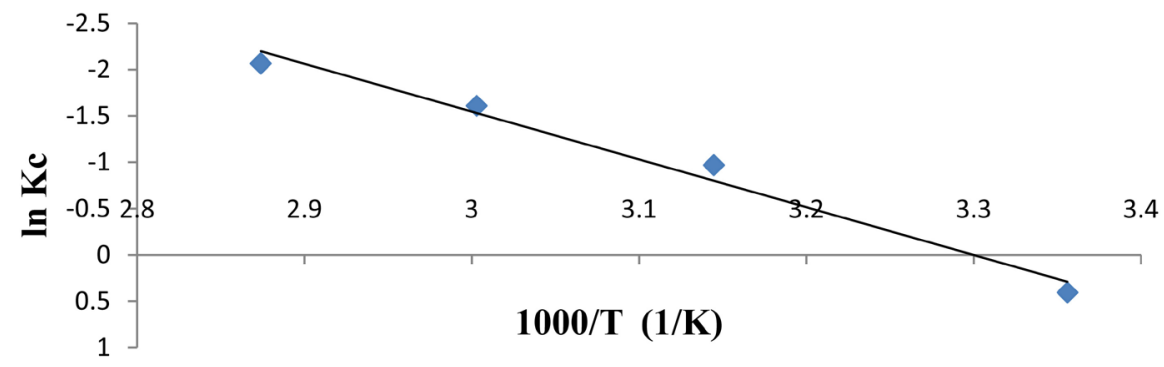

Figure 19. Thermodynamic model plot for Adsorption of iron ions on HApMn.

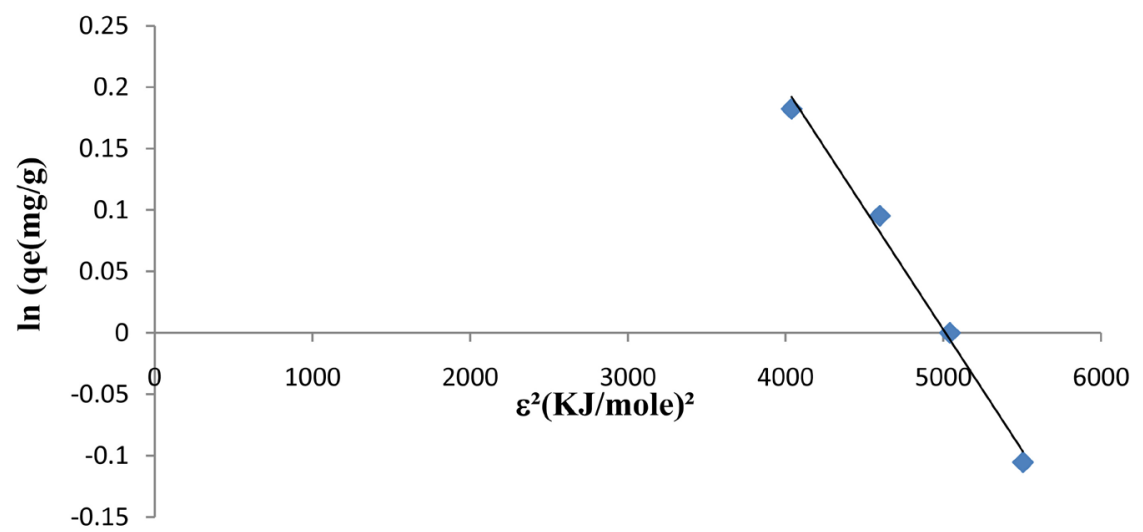

Figure 20. Dubinin-Radushkevick equation plot.

[40] equation, which assumes a constant sorption potential. The linear presentation of this equation is expressed by

$$
\begin{aligned}
& \ln q_{e}=\ln q_{m}-K_{E} \varepsilon^{2} \\
& \varepsilon=R T \ln \left(1+1 / C_{e}\right)
\end{aligned}
$$

where $\varepsilon$ is the Polanyi potential, $q_{t}$ is the monolayer capacity ( $\left.\mathrm{mol} / \mathrm{g}\right), C_{e}$ is the equilibrium concentration $\left(\mathrm{mol} / \mathrm{dm}^{3}\right)$, and $K_{E}$ is the constant related to sorption energy $\left(\mathrm{mol}^{2} / \mathrm{KJ}^{2}\right)$ The parameters $q_{t}$ and $K_{E}$ can be obtained from the intercept and slope of the plot as shown in Figure 20. The free energy of sorption $(E)$ is calculated by

$$
E=1 /\left(-2 K_{E}\right)^{1 / 2}
$$

Adsorption type could be estimated by evaluating of $E$ value. If this value is < $8,8-16$ or $>16 \mathrm{~kJ} / \mathrm{mol}$, the adsorption type can be explained by physical adsorption, ion-exchange, or chemical adsorption, respectively [41]. In this case, the 
adsorption is chemical adsorption at all temperatures because $E$ value was 50 $\mathrm{kJ} / \mathrm{mol}$.

\section{Conclusion}

In this article, we use Modified HApMn for removing iron ions from groundwater. Adsorption of iron on HApMn follows pseudo-second order kinetic model, Langmuir adsorption isotherm, Adsorption capacity from the Langmuir model is $0.604 \mathrm{mg} / \mathrm{g}$, the adsorption process is chemical type because adsorption energy value is $50 \mathrm{~kJ} / \mathrm{mol}$, and adsorption is favorable at low temperatures, the negative value of $\Delta H^{\circ}$ confirms that the sorption process is exothermic in nature and a given amount of heat is evolved during the binding iron ions on the surface of adsorbents.

\section{Acknowlegements}

It is my pleasure to express my deepest thanks to Chemistry Department, Faculty of Science, Helwan University, my thanks to Chemistry Department, Faculty of Science, Al-Azhar University, Assiut Branch, for his support and I thank Sohag Company for Water and Waste Water, Dar El Salam, Sohag, Egypt.

\section{Conflicts of Interest}

The authors declare no conflicts of interest regarding the publication of this paper.

\section{References}

[1] Hossain, D., Islam, M.S., Sultana, N. and Tusher, T.R. (2013) Assessment of Iron Contamination in Groundwater at Tangail Municipality, Bangladesh. Journal of Environmental Science and Natural Resources, 6, 117-121. https://doi.org/10.3329/jesnr.v6i1.22051

[2] Prentice, A.M., et al. (2017) Dietary Strategies for Improving Iron Status: Balancing Safety and Efficacy. Nutrition Reviews, 75, 49-60. https://doi.org/10.1093/nutrit/nuw055

[3] Abdennebi, N., Benhabib, K., Goutaudier, C. and Bagane, M. (2017) Removal of Aluminium and Iron Ions from Phosphoric Acid by Precipitation of Organo-Metallic Complex Using Organophosphorous Reagent. Journal of Materials and Environmental Science, 8, 557-565.

[4] Dubey, S., Banerjee, S., Upadhyay, S.N. and Sharma, Y.C. (2017) Application of Common Nano-Materials for Removal of Selected Metallic Species from Water and Wastewaters: A Critical Review. Journal of Molecular Liquids, 240, 656-677. https://doi.org/10.1016/j.molliq.2017.05.107

[5] Hosseini, H., Rezaei, H., Shahbazi, A. and Maghsudlu, A. (2016) Application of Nano-Lignocellulose for Removal of Nickel Ions from Aqueous Solutions. Environmental Resource Research, 4, 213-229.

[6] Piuleac, C.G., Sáez, C., Cañizares, P. and Curteanu, S. (2012) Hybrid Model of a Wastewater-Treatment Electrolytic Process. International Journal of Electrochemical Science, 7, 6289-6301. 
[7] Mondal, P., Majumder, C.B. and Mohanty, B. (2008) Effects of Adsorbent Dose, Its Particle Size and Initial Arsenic Concentration on the Removal of Arsenic, Iron and Manganese from Simulated Ground Water by Fe3+ Impregnated Activated Carbon. Journal of Hazardous Materials, 150, 695-702. https://doi.org/10.1016/j.jhazmat.2007.05.040

[8] Javadian, H., Ghorbani, F., Tayebi, H. and Asl, S.H. (2015) Study of the Adsorption of Cd (II) from Aqueous Solution Using Zeolite-Based Geopolymer, Synthesized from Coal Fly Ash; Kinetic, Isotherm and Thermodynamic Studies. Arabian Journal of Chemistry, 8, 837-849. https://doi.org/10.1016/j.arabjc.2013.02.018

[9] Agarwal, S., et al. (2016) Efficient Removal of Toxic Bromothymol Blue and Methylene Blue from Wastewater by Polyvinyl Alcohol. Journal of Molecular Liquids, 218, 191-197. https://doi.org/10.1016/j.molliq.2016.02.060

[10] Bhatnagar, A. and Sillanpää, M. (2017) Removal of Natural Organic Matter (NOM) and Its Constituents from Water by Adsorption-A Review. Chemosphere, 166, 497-510. https://doi.org/10.1016/j.chemosphere.2016.09.098

[11] Mrinal, D.D., Adak, K., Mondal, B., Dhak, P. and Sen, S. (2017) A Comparative Study on Fluoride Removal Capacity from Drinking Water by Adsorption Using Nano-Sized Alumina and Zirconia Modified Alumina Prepared by Chemical Route. Advances in Water Science and Technology, 4, 1-10.

[12] Abuh, M.A., Akpomie, G.K., Nwagbara, N.K., Abia-Bassey, N., Ape, D.I. and Ayabie, B.U. (2013) Kinetic Rate Equations Application on the Removal of Copper (II) and Zinc (II) by Unmodified Lignocellulosic Fibrous Layer of Palm Tree Trunk-Single Component System Studies. International Journal of Basic and Applied Sciences, 50, 800-809.

[13] Elhafez, S.E.A., Hamad, H.A., Zaatout, A.A. and Malash, G.F. (2017) Management of Agricultural Waste for Removal of Heavy Metals from Aqueous Solution: Adsorption Behaviors, Adsorption Mechanisms, Environmental Protection, and Techno-Economic Analysis. Environmental Science and Pollution Research, 24, 1397-1415. https://doi.org/10.1007/s11356-016-7891-7

[14] Voisin, H., Bergström, L., Liu, P. and Mathew, A. (2017) Nanocellulose-Based Materials for Water Purification. Nanomaterials, 7, 57. https://doi.org/10.3390/nano7030057

[15] Bhadra, B.N., Ahmed, I., Kim, S. and Jhung, S.H. (2017) Adsorptive Removal of Ibuprofen and Diclofenac from Water Using Metal-Organic Framework-Derived Porous Carbon. Chemical Engineering Journal, 314, 50-58.

https://doi.org/10.1016/j.cej.2016.12.127

[16] Wang, X., Liang, Y., An, W., Hu, J., Zhu, Y. and Cui, W. (2017) Removal of Chromium (VI) by a Self-Regenerating and Metal Free g- $\mathrm{C}_{3} \mathrm{~N}_{4} / \mathrm{Graphene} H y d r o g e l$ System via the Synergy of Adsorption and Photo-Catalysis under Visible Light. Applied Catalysis B: Environmental, 219, 53-62.

https://doi.org/10.1016/j.apcatb.2017.07.008

[17] Sarker, M., Bhadra, B.N., Seo, P.W. and Jhung, S.H. (2017) Adsorption of Benzotriazole and Benzimidazole from Water over a Co-Based Metal Azolate Framework MAF-5(Co). Journal of Hazardous Materials, 324, 131-138.

https://doi.org/10.1016/j.jhazmat.2016.10.042

[18] Elkady, M.F., Mahmoud, M.M. and Abd-El-Rahman, H.M. (2011) Kinetic Approach for Cadmium Sorption Using Microwave Synthesized Nano-Hydroxyapatite. Journal of Non-Crystalline Solids, 357, 1118-1129. https://doi.org/10.1016/j.jnoncrysol.2010.10.021 
[19] Gotić, M., Jurkin, T., Musić, S., Unfried, K., Sydlik, U. and Bauer-Šegvić, A. (2013) Microstructural Characterizations of Different Mn-Oxide Nanoparticles Used as Models in Toxicity Studies. Journal of Molecular Structure, 1044, 248-254. https://doi.org/10.1016/j.molstruc.2012.09.083

[20] Abdel Ghafar, H.H., Ali, G.A.M., Fouad, O.A. and Makhlouf, S.A. (2015) Enhancement of Adsorption Efficiency of Methylene Blue on Co3O4/SiO2 Nanocomposite. Desalination and Water Treatment, 53, 2980-2989.

https://doi.org/10.1080/19443994.2013.871343

[21] Hamdaoui, O. (2017) Adsorption of $\mathrm{Cu}(\mathrm{II})$ from Aqueous Phase by Cedar Bark. Journal of Dispersion Science and Technology, 38, 1087-1091. https://doi.org/10.1080/01932691.2016.1225261

[22] Gupta, V.K., Agarwal, S., Sadegh, H., Ali, G.A.M., Bharti, A.K. and Hamdy Makhlouf, A.S. (2017) Facile Route Synthesis of Novel Graphene Oxide- $\beta$-Cyclodextrin Nanocomposite and Its Application as Adsorbent for Removal of Toxic Bisphenol A from the Aqueous Phase. Journal of Molecular Liquids, 237, 466-472. https://doi.org/10.1016/j.molliq.2017.04.113

[23] Gomaa, H., Gomaa, A., Farid, M., Cheira, M., Ahmed, T. and Seaf, S.E.T.A. (2016) Removal of Uranium from Acidic Solution Using Activated Carbon Impregnated with Tri Butyl Phosphate. Biological and Chemical Research, 313-340.

[24] Gomaa, H., et al. (2018) Highly-Efficient Removal of $\mathrm{AsV}, \mathrm{Pb}^{2+}, \mathrm{Fe}^{3+}$ and $\mathrm{Al}^{3+} \mathrm{Pol}-$ lutants from Water Using Hierarchical, Microscopic $\mathrm{TiO}_{2}$ and $\mathrm{TiOF}_{2}$ Adsorbents through Batch and Fixed-Bed Columnar Techniques. Journal of Cleaner Production, 182, 910-925. https://doi.org/10.1016/j.jclepro.2018.02.063

[25] Abd El-Latif, M.M. and Elkady, M.F. (2011) Kinetics Study and Thermodynamic Behavior for Removing Cesium, Cobalt and Nickel Ions from Aqueous Solution Using Nano-Zirconium Vanadate Ion Exchanger. Desalination, 271, 41-54. https://doi.org/10.1016/j.desal.2010.12.004

[26] Elnasr, A.T.S., Soliman, M.H. and Ayash, M.A.-E.-A.A. (2017) Modified Hydroxyapatite Adsorbent for Removal of Iron Dissolved in Water Wells in Sohag, Egypt. Chemistry of Advanced Materials, 1, 1-13.

[27] Habeeb, O.A., et al. (2016) Modeling and Optimization for H2S Adsorption from Wastewater Using Coconut Shell Based Activated Carbon. Australian Journal of Basic and Applied Sciences, 10, 136-147.

[28] Shah, A.F.S., Ajit, M.S. and Usmani, G.A. (2016) Kinetics Modelling Study: Adsorption of Victoria Blue on Mahaneem Leaf Powder. International Journal of Advanced Scientific and technical Research, 1, 293-302.

[29] Habeeb, O.A., et al. (2016) Modeling and Optimization for H2S Adsorption from Wastewater Using Coconut Shell Based Activated Carbon. Australian Journal of Basic and Applied Sciences, 10, 136-147.

[30] Dehghani, M.H., Sanaei, D., Ali, I. and Bhatnagar, A. (2016) Removal of Chromium (VI) from Aqueous Solution Using Treated Waste Newspaper as a Low-Cost Adsorbent: Kinetic Modeling and Isotherm Studies. Journal of Molecular Liquids, 215, 671-679. https://doi.org/10.1016/j.molliq.2015.12.057

[31] Ioannou, Z. and Simitzis, J. (2009) Adsorption Kinetics of Phenol and 3-Nitrophenol from Aqueous Solutions on Conventional and Novel Carbons. Journal of Hazardous Materials, 171, 954-964. https://doi.org/10.1016/j.jhazmat.2009.06.098

[32] Romero-González, J., Peralta-Videa, J.R., Rodrí́guez, E., Ramirez, S.L. and Gardea-Torresdey, J.L. (2005) Determination of Thermodynamic Parameters of Cr(VI) Adsorption from Aqueous Solution onto Agave lechuguilla Biomass. The Journal of 
Chemical Thermodynamics, 37, 343-347. https://doi.org/10.1016/j.jct.2004.09.013

[33] Zamani, S., Salahi, E. and Mobasherpour, I. (2013) Removal of Nickel from Aqueous Solution by Nano Hydroxyapatite Originated from Persian Gulf Corals. Canadian Chemical Transactions, 1, 173-190. https://doi.org/10.13179/canchemtrans.2013.01.03.0033

[34] Demirkıran, N., Özdemir, G.D.T., Saraç, M. and Dardağan, M. (2017) Adsorption of Methylene Blue from Aqueous Solutions by Pyrolusite Ore. Mongolian Journal of Chemistry, 18, 5-11. https://doi.org/10.5564/mjc.v18i44.880

[35] Kooh, M.R.R., Lim, L.B.L., Lim, L.H. and Dahri, M.K. (2016) Separation of Toxic Rhodamine B from Aqueous Solution Using an Efficient Low-Cost Material, Azolla pinnata, by Adsorption Method. Environmental Monitoring and Assessment, 188, 1-15. https://doi.org/10.1007/s10661-016-5108-7

[36] Wang, W. and Wang, J. (2018) Comparative Evaluation of Sorption Kinetics and Isotherms of Pyrene onto Microplastics. Chemosphere, 193, 567-573.

https://doi.org/10.1016/j.chemosphere.2017.11.078

[37] Foroutan, R., Esmaeili, H., Abbasi, M., Rezakazemi, M. and Mesbah, M. (2018) Adsorption Behavior of $\mathrm{Cu}(\mathrm{II})$ and $\mathrm{Co}(\mathrm{II})$ Using Chemically Modified Marine Algae. Environmental Technology, 39, 2792-2800. https://doi.org/10.1080/09593330.2017.1365946

[38] Lima, E.C., Hosseini-Bandegharaei, A., Moreno-Piraján, J.C. and Anastopoulos, I. (2019) A Critical Review of the Estimation of the Thermodynamic Parameters on Adsorption Equilibria. Wrong Use of Equilibrium Constant in the Van't Hoof Equation for Calculation of Thermodynamic Parameters of Adsorption. Journal of Molecular Liquids, 273, 425-434. https://doi.org/10.1016/j.molliq.2018.10.048

[39] Labib, S.A., Yousif, A.M., Ibrahim, I.A. and Atia, A.A. (2018) Adsorption of Rhodium by Modified Mesoporous Cellulose/Silica Sorbents: Equilibrium, Kinetic, and Thermodynamic Studies. Journal of Porous Materials, 25, 383-396. https://doi.org/10.1007/s10934-017-0449-3

[40] Kamga, F.T. (2019) Modeling Adsorption Mechanism of Paraquat onto Ayous ( Triplochiton scleroxylon) Wood Sawdust. Applied Water Science, 9, 1. https://doi.org/10.1007/s13201-018-0879-3

[41] Khatibikamal, V., Panahi, H.A., Torabian, A. and Baghdadi, M. (2019) Optimized Poly(amidoamine) Coated Magnetic Nanoparticles as Adsorbent for the Removal of Nonylphenol from Water. Microchemical Journal, 145, 508-516. https://doi.org/10.1016/j.microc.2018.11.018 